\title{
Patient-controlled analgesia and morphine consumption in sickle cell anemia painful crises: A new protocol
}

\author{
Orak hücre anemisi ağrılı krizlerinde hasta kontrollü analjezi ile morfin tüketimi: \\ Yeni bir protokol
}

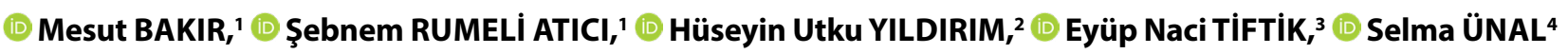

\begin{abstract}
Summary
Objectives: The sudden and rapidly increasing severity of pain in sickle cell anemia painful crises frequently requires the use of strong opioids. Patients require continuous administrations of various doses (increased/decreased) within the following hours. This study aims to retrospectively evaluate the effects of a structured protocol based on standardized Visual Analogue Scale (VAS) and Patient-controlled analgesia (PCA) patient demand count on morphine consumption in painful crises.
\end{abstract}

Methods: A total of 177 painful crises of 93 patients who were administered morphine using the PCA method according to appropriate analgesia protocol between 2004-2018 were evaluated in this study. The demographic data, hemoglobin chromatography and genotypes, painful episode follow-up time, VAS scores before and after treatment, and daily morphine consumption of the patients were recorded. Morphine consumption during the crisis according to age groups and sex were compared. Results: Of the patients, 57\% were homozygous hemoglobin type SS (HbSS). Mean morphine consumption with PCA method was $56.9 \pm 35.4 \mathrm{mg}$ (min-max: 10-232 mg) and mean follow-up time was $3.4 \pm 2.1$ days (min.-max.: 1-11). VAS scores were significantly lower after treatment ( $6.8 \pm 2.3$ pre-treatment; $0.8 \pm 0.6$ post-treatment) $(p<0.05)$.

Conclusion: To our knowledge, our study is the first structured protocol based on VAS and PCA demand data. We believe lower morphine dosage using PCA protocol according to the rapidly changing pain levels of the patients will provide effective analgesia. Prospective studies with fewer limitations will more effectively demonstrate the effectiveness of this protocol.

Keywords: Analgesia protocol; morphine; painful crises; patient controlled analgesia; sickle cell anemia.

\section{Özet}

Amaç: Orak hücreli aneminin ağrılı krizlerinde ağrının ani gelişen ve hızla yükselen şiddeti, sıklıkla güçlü opioid kullanımı gerektirmektedir. Bununla birlikte hastalar saatler içerisinde sürekli farklı doz (arttırma/azaltma) uygulamalarına ihtiyaç duymaktadırlar. Bu çalışma ile retrospektif olarak, ağıııı krizlerde, standardizasyonu görsel ağı skalası (VAS) ve hasta kontrollü analjezi yöntemindeki (HKA) hasta istek sayısına göre yapılandırılmış bir protokolün, morfin tüketimi üzerine etkisinin değerlendirilmesi amaçlandı.

Gereç ve Yöntem: 2004-2018 yılları arasında, analjezisi için protokole uygun olarak, HKA yöntemi ile morfin uygulanan, 93 hastanın 177 ağrılı krizi incelendi. Hastaların demografik verileri, hemoglobin kromotografileri ve genotipleri, ağrılı dönem takip süresi, tedavi öncesi ve sonrası VAS değerleri, günlük morfin tüketimleri kaydedildi. Yaş grupları ve cinslere göre ağrılı kriz dönemi morfin tüketimleri karşılaştırıldı.

Bulgular: Hastaların \%57'sinin homozigot tip olan Hb SS olduğu görüldü. HKA yöntemi ile ortalama morfin tüketimi 56.9 \pm 35.4 mg (en düşük-en yüksek/10 mg-232 mg), ortalama takip süresi 3.4 \pm 2.1 gün (en düşük-en yüksek/1-11) idi. Hastaların VAS değerleri, tedavi öncesine göre tedavi sonrasında istatistiksel olarak düşük bulundu (sırasıyla, $6.8 \pm 2.3,0.8 \pm 0.6)(p<0.05)$.

Sonuç: Bu çalışmamız, VAS ve HKA istek verilerine göre yapılandııımış ilk protokoldür. Hastaların hızla değişen ağrı düzeylerine göre programlanan HKA protokolümüz ile daha düşük düzeylerde morfin kullanılarak etkin analjezinin sağlanabildiği kanısındayız. Limitasyonların azaltılabileceği prospektif çalışmalarla protokolün etkinliğinin daha net ortaya konabileceğini düşünmekteyiz.

'Department of Algology, Mersin University Faculty of Medicine, Mersin, Turkey

2Department of Algology, Antalya Training and Research Hospital, Antalya, Turkey

${ }^{3}$ Department of Hematology, Mersin University Faculty of Medicine, Mersin, Turkey

${ }^{4}$ Department of Pediatric Hematology, Mersin University Faculty of Medicine, Mersin, Turkey

Submitted (Başvuru tarihi) 02.09.2019 Accepted after revision (Düzeltme sonrası kabul tarihi) 13.01.2020 Available online date (Online yayımlanma tarihi) 05.05.2020

Correspondence: Dr. Şebnem Rumeli AtııI. Mersin Üniversitesi Tıp Fakültesi, Algoloji Kliniği, 33130 Çiftlikköy, Yenişehir, Mersin, Turkey.

Phone: +90 - 506 - 3337733 e-mail: sebnematici@hotmail.com

(-) 2020 Turkish Society of Algology 


\section{Introduction}

Sickle-cell anemia (SCA) is a common life-threatening hematologic disease that affects millions of people throughout the world. ${ }^{[1]}$ Approximately 305.800 newborns were born with SCA in the year 2010 and this number is estimated to rise to 404.200 by the year 2050. ${ }^{[2]}$ Painful crises are the main cause of hospitalizations in these patients (over 90\%). Crises are defined as the clinical condition that occurs with acute ischemic changes in tissues, as a result of sickled erythrocytes adhering to endothelium and preventing microcirculation. ${ }^{[3-5]}$ The acute and increasingly severe character of the pain often requires use of strong analgesics. Quality of life is severely impaired during this period. ${ }^{[6]}$ It has been reported that $37 \%$ of patients hospitalized due to painful crises have experienced three or more recurrent crises within a year. ${ }^{[7]}$

While the acute and increasing severity of the painful episodes in SCA patients often require use of strong opioids, continuous changes in dosage (increase/ decrease) are needed within hours, depending on the efficacy of non-analgesic treatment. ${ }^{[8,9]}$ Therefore, opioids are administered on an as-needed basis for analgesia in painful crises..$^{[10,11]}$ Most clinicians prefer opioid administration with basal infusion and patient-controlled analgesia (PCA) method programmed with demand doses. ${ }^{[12]}$ The PCA method has also been found to be effective by health personnel and parents in pediatric patients diagnosed with SCA. ${ }^{[13]}$

There is no widely accepted standardized protocol for analgesic treatment of painful crises. ${ }^{[14]}$ Studies have shown that the PCA method has lower opioid consumption, only compared to continuous infusion method. ${ }^{[15]}$ Furthermore, there are only few studies in the literature on establishing PCA protocol for treatment of SCA painful crises. ${ }^{[15,16]}$ While the American National Health Institute guidelines published in 2014, and the England National Health Service guidelines published in 2012 and updated in 2016 have recommended steps for painful crises treatment, a flowchart for PCA programming has not been determined. ${ }^{[17,18]}$

The Hematology and Algology departments of our hospital use a structured analgesia protocol based on standardized Visual Analogue Scale (VAS) and patient demand of the PCA method for treatment of painful crises since 2004. Our study aims to evaluate the morphine consumption of patients administered analgesia under this protocol.

\section{Material and Methods}

By obtaining ethics committee approval, records of 132 patients over 18 years of age, diagnosed with SCA and hospitalized due to painful crises between the years 2004-2018 were evaluated. The 39 patients who were not administered morphine using the PCA method were excluded from the study. The 233 painful crises of the remaining 93 patients who were included in the study were assessed. Fifty-six painful crises were determined to have been treated with a combination of various opioids along with morphine, and were excluded from the study. The demographic data, follow-up period for each crisis, VAS scores before and after treatment, and daily morphine consumption of the 177 patients with painful crises were recorded from algology follow-up records. The morphine consumption and hospitalization length during painful crisis period were compared according to age groups and sex. The hemoglobin subgroups, genotypes, hemogram values, and hydroxyurea administrations of the patients were recorded. Patients diagnosed with acute chest syndrome at least once during hospitalization and mean number of yearly painful crises were also recorded.

\section{Analgesia protocol of painful crises}

The Hematology and Algology departments of our hospital have followed a protocol for treatment of painful crises since 2004 (Fig. 1). According to this protocol: patients with VAS $\geq 4$ despite intravenous (IV) paracetamol 4x1000 mg and peroral (po) ibuprofen $3 \times 800 \mathrm{mg}$ undergo consultation by the algology department. During the initial evaluation, IV bolus morphine $1 \mathrm{mg}$ and, if necessary, IV $0.5 \mathrm{mg}$ morphine at five-minute intervals are administered for reduced to below VAS 4. At the same time, PCA IV morphine infusion is initiated (infusion: $1 \mathrm{mg} / \mathrm{s}+$ bolus dose: 1 mg; lockout interval: $15 \mathrm{~min}$ ). Patients are evaluated bedside at least twice daily at $08.00-16.00$. When demand number is $<6$ at evaluation, dosage is adjusted to $0.5 \mathrm{mg} / 0.5 \mathrm{mg} / 15 \mathrm{~min}$. When demand count is less than 6 , infusion is stopped $(0.5 \mathrm{mg} / 15 \mathrm{~min})$. 


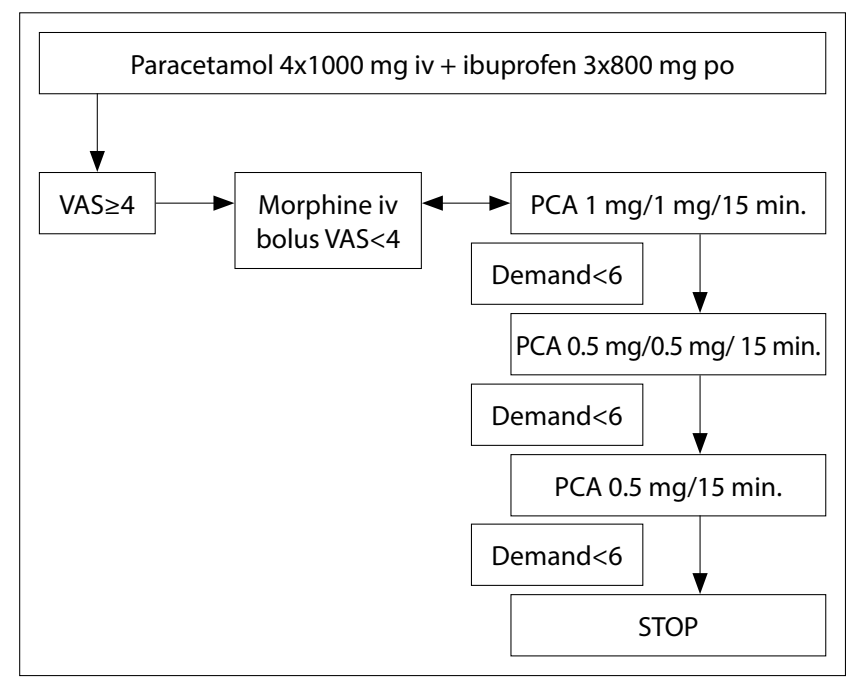

Figure 1. PCA analgesia protocol of painful crises.

VAS: Visual analogue scale; PCA: Pacient controlled analgesia.

When demand count is less than six during followup, PCA is discontinued. The patient continues to receive paracetamol and ibuprofen during the rest of the period.

\section{Statistical analysis}

For statistical analysis, the "Statistical Package for the Social Sciences version 22 (SPSS v.22)" program and the "e-PICOS" program was used for calculations based on "MedicReS Good Biostatistical Practice". Descriptive statistics was used for categorical variables and frequency calculations were expressed as percentage. Chi-square test was used for crosstabulations. Independent group t-test and dependent group t-test were used for comparison of mean values. The value $p<0.05$ was considered statistically significant.

\section{Results}

Follow-up periods of 177 painful crises of 93 patients were investigated. Fifty-two percent of the patients were male (M/F: 48/45). Mean age was $28.53 \pm 8.5$ years (mean-max: 18-61). As for hemoglobin genotypes, $57 \%$ of patients were homozygous type HbSS. According to patient chromatography, while the major prognostic factor of $\mathrm{HbF}$ levels were $9.1 \% \pm 5.3$, $\mathrm{HbS}$ levels were $76.6 \% \pm 10.1$. Mean hemoglobin level before painful crisis was $8.4 \pm 1.1 \mathrm{gr} / \mathrm{dL}$ (range: 5.7-11.4) (Table 1). Acute chest syndrome was diagnosed in $50.6 \%(n=47)$ of the patients. Regular hydroxyurea use was observed in $82 \%(n=76)$ of the patients. Mean number of yearly painful crises was $3.2 \pm 2.8$ /year (range: 1-12).
Table 1. Hemoglobin genotypes and chromatography

\begin{tabular}{lcc}
\hline Hemoglobin genotype & & \\
SS $(n, \%)$ & $53(57)$ & \\
SB $(n, \%)$ & $40(43)$ & \\
Chromatography & Mean & Min.-Max. \\
HbA & $7.3 \pm 11.0$ & $(0-39)$ \\
HbA2 & $4.0 \pm 1.0$ & $(0.9-7.7)$ \\
HbF & $9.1 \pm 5.3$ & $(0.0-22.3)$ \\
HbS & $76.6 \pm 10.1$ & $(40.1-94.2)$ \\
Hemoglobin (gr/dL) & $8.4 \pm 1.1$ & $(5.7-11.4)$ \\
\hline
\end{tabular}

Min.: Minimum; Max.: Maximum.

Table 2. Patient follow-up and analgesic data

\begin{tabular}{lcc}
\hline & Mean & Min.-Max. \\
\hline $\begin{array}{l}\text { Follow-up length } \\
\text { per crisis (days) }\end{array}$ & $3.43 \pm 2.1$ & $1-11$ \\
$\begin{array}{l}\text { Total morphine consumption } \\
\text { per crisis (mg) }\end{array}$ & $56.9 \pm 35.4$ & $10-232$ \\
$\begin{array}{l}\text { Mean number of yearly } \\
\text { painful crises }\end{array}$ & $3.2 \pm 2.8$ & $1-12$ \\
\hline
\end{tabular}

Min.: Minimum; Max.: Maximum.

Table 3. Distribution of follow-up length and morphine consumption according to age groups and sex

\begin{tabular}{lcc}
\hline & $\begin{array}{c}\text { Follow-up } \\
\text { (days) }\end{array}$ & $\begin{array}{c}\text { Morphine } \\
\text { consumption (mg) }\end{array}$ \\
\hline Sex & & \\
$\quad$ Female & $3.86 \pm 2.3$ & $56.1 \pm 30.1$ \\
$\quad$ Male & $3.51 \pm 1.9$ & $57.6 \pm 40.1$ \\
Age groups (years) & & \\
$\quad$ 18-23 & $3.6 \pm 1.7$ & $54.7 \pm 30.9$ \\
$24-29$ & $3.7 \pm 2.4$ & $61.8 \pm 41.3$ \\
$30-61$ & $3.6 \pm 2.1$ & $55.1 \pm 35.2$ \\
\hline
\end{tabular}

Mean follow-up time of hospitalized patients under PCA protocol was $3.4 \pm 2.1$ days (range: $1-11$ ) (Table 2). Mean morphine consumption during painful crisis period was $56.9 \pm 35.4 \mathrm{mg}(10-232 \mathrm{mg})$. Highest IV bolus morphine dose administered upon hospital admittance was $12 \mathrm{mg}$. There was no significant difference in morphine consumption or crisis follow-up period according to age groups or sex ( $p>0.05$ ) (Table 3 ).

While mean VAS scores before PCA method morphine treatment was $6.8 \pm 2.3$, these scores decreased to $0.8 \pm 0.6$ after treatment (Fig. 2). 


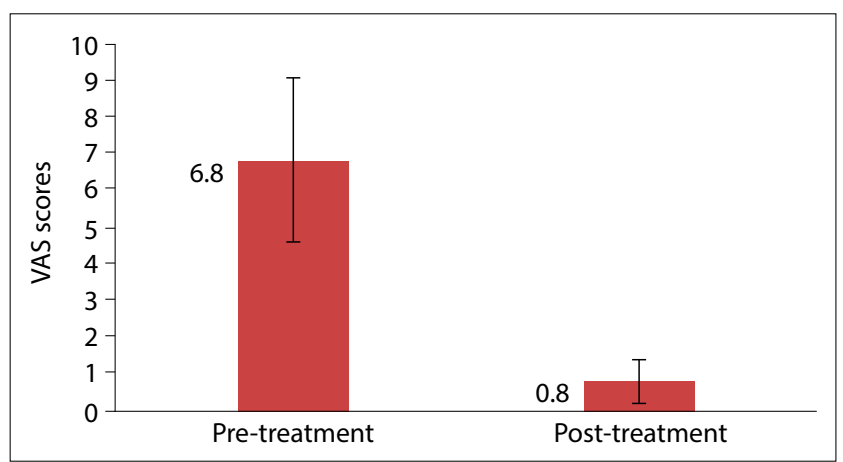

Figure 2. VAS scores before and after morphine administration with PCA. $p<0.05$.

\section{Discussion}

Our study includes the first analgesia protocol that dynamically manages rapidly changing pain according to VAS scores and PCA demand in painful crises. It is also the most comprehensive study to evaluate morphine consumption with the PCA method using a standard protocol in SCA painful crises. The protocol demonstrates that effective analgesia can be achieved with low morphine dosage.

The literature states that age, genotype, hydroxyurea use, HbF levels, and presence of acute chest syndrome are all important factors in the severity of painful crises. According to age, the highest incidence is between ages $18-30 .^{[19]}$ In our study, mean age was $28.53 \pm 8.5$. Tyagi et al. ${ }^{[20]}$ reported that painful crises were more frequent in HbSS genotype patients (62.5\%) compared to HbSB patients, but was not statistically significant. Serjeant et al. ${ }^{[21]}$ indicated that HbSS and HbSB were the most significant patient genotypes. In our study, the most significant genotypes were HbSS (57\%) and Hb SB (43\%). Pahl et al. ${ }^{[22]}$ evaluated 109 patients and observed that $50 \%$ of $\mathrm{HbSS}$ and HbSB genotype patients were diagnosed with acute chest syndrome (ACS) at least once during hospitalization due to painful crisis. In our patients, $50.6 \%$ were diagnosed with ACS during painful crisis. Hydroxyurea treatment was shown to reduce the frequency of painful crises by increasing $\mathrm{HbF}$ levels and reducing production of adhesion molecules. ${ }^{[23-25]}$ While patients with high HbF levels experience milder painful crises, they are more severe in patients with lower levels. ${ }^{[26,27]}$ Although $82 \%$ of our patients were receiving hydroxyurea treatment, their HbF levels $(9.1 \% \pm 5.3)$ were consistent with the severe painful form. According to the results of the study, it was concluded that the patients possessed serious risk factors for painful crises.
In a meta-analysis by Ballas et al., ${ }^{[3]}$ it was reported that severe painful crises lasted on average of 9-11 days, with the most painful period starting on the third day, and pain decreasing on the sixth-seventh day. In our study, we observed that the mean followup period of painful crises managed with the PCA method was $3.4 \pm 2.1$ days. The mean follow-up period of our patients was similar to the established painful crisis cycle.

Al-Anazi et al. ${ }^{[28]}$ compared intermittent IV administration and PCA method in SCA painful crises in a retrospecitve study. It was reported that, with PCA method, mean morphine consumption of the patients within 72 hours was $777 \pm 175 \mathrm{mg}$. The mean morphine consumption with PCA method in our study $(56.9 \pm 35.4)$ was relatively lower than other studies that evaluated morphine consumption in painful crises. Van Beers et al. ${ }^{[15]}$ compared morphine consumption of PCA and continuous infusion methods in SCA patients with painful crises. The aforementioned study found morphine consumption was lower with PCA method compared to continuous infusion (PCA: $33 \mathrm{mg}$; continuous infusion: $260 \mathrm{mg}$ ). Although the low dosage was reported in the PCA group, the lowest mean VAS scores was over 4 . We believe these VAS scores are insufficient to be considered as effective analgesia. In our study, VAS scores before treatment (6.8 \pm 2.3$)$ were consistent with the literature, however, the fact that our VAS scores after treatment $(0.8 \pm 0.6)$ were relatively lower suggests that our PCA protocol for analgesia is substantially effective.

The retrospective nature was a limitation of our study. However, application of a standard protocol for treatment and twice daily evaluation of the patients reduces this limitation. The lack of satisfaction scores of the patients after treatment, using patient satisfaction scales, was another limitation of our study. The fact that pain scores were recorded twice a day using VAS scale, and that patients had active participation in analgesia in the scope of the protocol reduces this limitation.

\section{Conclusion}

Our study is the first structured protocol according to VAS and PCA demand numbers. We believe that lower doses of morphine using programmed PCA protocol according to the rapidly changing pain levels of patients can provide effective analgesia. The 
effectiveness of the protocol would be clarified with prospective studies with reduced limitations.

\section{Ethics Committee Approval: The Mersin University Human Research Ethics Review Board granted ap- proval for this study (date: 12.07.2018, number: 78017789/050.01.04/E.786416).}

\section{Author Contributions: Mesut Bakır, Şebnem Rumeli Atıcı and Hüseyin Utku YıIdırım performed the research, Me- sut Bakır and Şebnem Rumeli Atıcı designed the research study and analysed the data, Mesut Bakır, Şebnem Ru- meli Atıcı, Naci Tiftik and Selma Ünal wrote the paper. \\ Conflict-of-interest issues regarding the authorship or article: None declared.}

\section{Peer-rewiew: Externally peer-reviewed.}

\section{References}

1. Ware RE, de Montalembert M, Tshilolo L, Abboud MR. Sickle cell disease. Lancet 2017;390(10091):311-23. [CrossRef]

2. Piel FB, Patil AP, Howes RE, Nyangiri OA, Gething PW, Dewi $M$, et al. Global epidemiology of sickle haemoglobin in neonates: a contemporary geostatistical model-based map and population estimates. Lancet 2013;381(9861):142-51.

3. Ballas SK. Pain management of sickle cell disease. Hematol Oncol Clin North Am 2005;19(5):785-802. [CrossRef]

4. Ballas SK, Gupta K, Adams-Graves P. Sickle cell pain: a critical reappraisal. Blood 2012;120(18):3647-56. [CrossRef]

5. Dampier CD, Smith WR, Wager CG, Kim HY, Bell MC, Miller ST, et al; Sickle Cell Disease Clinical Research Network (SCDCRN). IMPROVE trial: a randomized controlled trial of patient-controlled analgesia for sickle cell painful episodes: rationale, design challenges, initial experience, and recommendations for future studies. Clin Trials 2013;10(2):319-31.

6. Gupta M, Msambichaka L, Ballas SK, Gupta K. Morphine for the treatment of pain in sickle cell disease. ScientificWorldJournal 2015;2015:540154. [CrossRef]

7. Lin RJ, Evans AT, Wakeman K, Unterbrink M. A Mixed-Methods Study of Pain-related Quality of Life in Sickle Cell VasoOcclusive Crises. Hemoglobin 2015;39(5):305-9. [CrossRef]

8. Tanabe P, Silva S, Bosworth HB, Crawford R, Paice JA, Richardson $L D$, et al. A randomized controlled trial comparing two vaso-occlusive episode (VOE) protocols in sickle cell disease (SCD). Am J Hematol 2018;93(2):159-68. [CrossRef]

9. Uwaezuoke SN, Ayuk AC, Ndu IK, Eneh Cl, Mbanefo NR, Ezenwosu OU. Vaso-occlusive crisis in sickle cell disease: current paradigm on pain management. J Pain Res 2018;11:3141-50. [CrossRef]

10. Ruta NS, Ballas SK. The Opioid Drug Epidemic and Sickle Cell Disease: Guilt by Association. Pain Med 2016;17(10):179398. [CrossRef]

11. Telfer P, Bahal N, Lo A, Challands J. Management of the acute painful crisis in sickle cell disease- a re-evaluation of the use of opioids in adult patients. $\mathrm{Br} \mathrm{J}$ Haematol 2014;166(2):157-64. [CrossRef]

12. Miller ST, Kim HY, Weiner D, Wager CG, Gallagher D, Styles $\mathrm{L}$, et al; Investigators of the Sickle Cell Disease Clinical Re- search Network (SCDCRN). Inpatient management of sickle cell pain: a 'snapshot' of current practice. Am J Hematol 2012;87(3):333-6. [CrossRef]

13. Turaç $A$, Rumeli Atıcı Ş. Evaluation of the effectiveness of patient-controlled analgesia in children with sickle cell anemia from the perspective of healthcare professionals and parents. Agri 2016;28(3):150-4. [CrossRef]

14. Telfer P, Kaya B. Optimizing the care model for an uncomplicated acute pain episode in sickle cell disease. Hematology Am Soc Hematol Educ Program 2017(1):525-33.

15. van Beers EJ, van Tuijn CF, Nieuwkerk PT, Friederich PW, Vranken JH, Biemond BJ. Patient-controlled analgesia versus continuous infusion of morphine during vaso-occlusive crisis in sickle cell disease, a randomized controlled trial. Am J Hematol 2007;82(11):955-60. [CrossRef]

16. Dampier CD, Smith WR, Kim HY, Wager CG, Bell MC, Minniti $C P$, et al; Investigators of the Sickle Cell Disease Clinical Research Network (SCDCRN). Opioid patient controlled analgesia use during the initial experience with the IMPROVE PCA trial: a phase III analgesic trial for hospitalized sickle cell patients with painful episodes. Am J Hematol 2011;86(12):E70-3. [CrossRef]

17. Buchanan GR, Yawn BP. Evidence-Based Management of Sickle Cell Disease: Expert Panel Report, 2014. Available at: https://www.nhlbi.nih.gov/sites/default/files/media/docs/ sickle-cell-disease-report\%20020816_0.pdf.

18. Centre for Clinical Practice at NICE (UK). Sickle Cell Acute Painful Episode: Management of an Acute Painful Sickle Cell Episode in Hospital. Manchester (UK): National Institute for Health and Clinical Excellence (UK); 2012.

19. Field JJ, Ballas SK, Campbell CM, Crosby LE, Dampier C, Darbari DS, et al. AAAPT Diagnostic Criteria for Acute Sickle Cell Disease Pain. J Pain 2019;20(7):746-59. [CrossRef]

20. Tyagi S, Choudhry VP, Saxena R. Subclassification of HbS syndrome: is it necessary? Clin Lab Haematol 2003;25(6):377-81.

21. Serjeant GR. The natural history of sickle cell disease. Cold Spring Harb Perspect Med 2013;3(10):a011783. [CrossRef]

22. Pahl K, Mullen CA. Original Research: Acute chest syndrome in sickle cell disease: Effect of genotype and asthma. Exp Biol Med (Maywood) 2016;241(7):745-58. [CrossRef]

23. Fernandes Q. Therapeutic strategies in Sickle Cell Anemia: The past present and future. Life Sci 2017;178:100-8.

24. Mozeleski BM, Al-Rubaish A, Al-Ali A, Romero J. Perspective: A Novel Prognostic for Sickle Cell Disease. Saudi J Med Med Sci 2018;6(3):133-6. [CrossRef]

25. Nevitt SJ, Jones AP, Howard J. Hydroxyurea (hydroxycarbamide) for sickle cell disease. Cochrane Database Syst Rev 2017;4(4):CD002202. [CrossRef]

26. Habara AH, Shaikho EM, Steinberg MH. Fetal hemoglobin in sickle cell anemia: The Arab-Indian haplotype and new therapeutic agents. Am J Hematol 2017;92(11):1233-42.

27. Steinberg $\mathrm{MH}$, Chui DH, Dover GJ, Sebastiani P, Alsultan A. Fetal hemoglobin in sickle cell anemia: a glass half full? Blood 2014;123(4):481-5. [CrossRef]

28. Al-Anazi A, Al-Swaidan L, Al-Ammari M, Al-Debasi T, Alkatheri AM, Al-Harbi $S$, et al. Assessment of patient-controlled analgesia versus intermittent opioid therapy to manage sickle-cell disease vaso-occlusive crisis in adult patients. Saudi J Anaesth 2017;11(4):437-41. [CrossRef] 